\title{
PROSES MANAJEMEN PERKANTORAN BADAN PUSAT STATISTIK (BPS) KABUPATEN PIDIE
}

\author{
Rozaili \\ Dosen Program Studi Ilmu Administrasi Negara, Fakultas Ilmu Administrasi Universitas Jabal Ghafur
}

\begin{abstract}
ABSTRAK
Setiap organisasi yang dibentuk, merupakan kerja sama antara beberapa orang yang mempunyai tujuan. Dalam proses pencapaian tujuan tersebut banyak faktor yang menentukan, salah satunya faktor manajemen yang teratur, berhasil tidaknya sebuah organisasi maupun lembaga sangat ditentukan dari tertib administrasi dan manajemen serta orang yang memimpin organisasi yang bersangkutan. Jelaslah bahwa penataan manajemen yang baik serta administrasi yang teratur sangat menentukan berhasilnya suatu usaha pada setiap proses manajemen untuk mencapai tujuan tertentu yang direncanakan.Tujuan dilakukan penelitian ini untuk mengetahui sejauh mana proses mananjemen perkantoran di Badan Pusat Statistik (BPS) Kabupaten Pidie dan faktor apa saja yang menjadi hambatan pelaksanaanya. Penulisan Skripsi ini menggunakan metode dikskriptis. Untuk memperoleh data penulis melakukan penelitian lapangan untuk memperoleh data primer. Penulis juga melakukan penelitian kepustakaan untuk memperoleh data sekunder, semua data yang diperoleh dari hasil penelitian diolah lalu dianalisis dengan mengunakan pendekatan kualitatif dan kuanlitatif. Dari hasil penelitian ditemukan bahwa proses manajemen perkantoran di Badan Pusat Statistik (BPS) Kabupaten Pidie belum terlaksana sebagaimana mestinya. Faktor yang menjadi penghambat adalah kurangnya sarana dan prasarana yang dimiliki dan kurangnya pemahaman pegawai terhadap tugas dan fungsinya. Diharapkan adanya perbaikan serta partisipasi semua pihak, disamping itu disarankan agar pihak yang bersangkutan dapat menata sebaik mungkin tata letak dan fungsi sarana peralatan kantor sehingga memperindah dan memudahkan dalam melaksanakan tugas dimasa datang.
\end{abstract}

\section{PENDAHULUAN}

Latar Belakang Masalah

Setiap kegiatan dalam suatu organisasi baik organisasi Pemerintahan maupun organisasi swasta memerlukan adanya manajemen yang teratur. Hal ini disebabkan berhasil tidaknya dari sebuah organisasi atau lembaga sangat ditentukan dari tertib administrasi dan manajemen serta orang yang memimpin organisasi yang bersangkutan.

Dalam hal ini dapat dilihat pada negaranegara yang telah maju mengenai pelaksanaan program kerja mereka pada umumnya telah berhasil merencanakan, menggerakkan, mengkoordinir dan mengintegrasikan serta dapat menyede rhanakan berbagai macam keahlian, kegiatan, disiplin ilmu dan perasaan menjadi satu mata rantai yang paling berkaitan antara satu dengan yang lainnya.

Dari uraian diatas jelaslah bahwa penataan manajemen yang baik serta administrasi yang teratur sangat menentukan berhasilnya suatu usaha pada setiap proses manajemen untuk mencapai tujuan tertentu yang direncanakan. Dewasa ini di Indonesia telah mulai berkembang dan dipraktekkan secara meluas seirama dengan perkembangannya. Akan tetapi apabila diperhatikan secara seksama masih banyak dijumpai hambatan-hambatan dan kesulitan, ini disebabkan pengaruh dari berbagai aspek yang sangat mempengaruhi proses manajemen dan organisasi itu sendiri.

Maka untuk mengatasi permasalahan tersebut pemerintah telah berusaha menempuh berbagai cara baik dengan pelatihan atau penataran dalam bidang kepegawaian maupun dengan menciptakan metode baru yang lebih berdaya guna dan berhasil guna, sehingga dapat menyempurnakan proses manajemen dan administrasi dengan melengkapi peralatan yang dilaksanakan secara terus-menerus.

Berdasarkan uraian diatas, maka dalam hal ini perlu dilakukan penyempurnaan manajemen perkantoran pada Badan Pusat Statistik (BPS) Kabupaten Pidie, yang teratur sedemikian rupa agar pelayanan terhadap masyarakat dapat terlaksana sebagaimana mestinya. Proses manajemen perkantoran Badan Pusat Statistik (BPS) Kabupaten Pidie dilakukan oleh pegawai yang diberi tugas untuk itu. Ada beberapa jenis manajemen perkantoran yang dilaksanakan Badan Pusat Statistik (BPS) Kabupaten Pidie, meliputi 
manajemen kepegawaian, sarana dan prasarana dan lain-lain yang berkenaan dengan kegiatan perkantoran atau ketatausahaan.

Keberadaan pegawai sebagai unsur pelaksana tugas yang menyangkut dengan proses manajemen perkantoran Badan Pusat Statistik (BPS) Kabupaten Pidie, diharapkan agar tugas-tugas tersebut dapat dilaksanakan secara berdaya guna, yang pada gilirannya keseluruhan tugas yang ada dapat berjalan sebagaimana yang diharapkan.

Beranjak kepada uraian-uraian diatas, dan berdasarkan pengamatan yang dilakukan oleh penulis menunjukan bahwa proses manajemen perkantoran Badan Pusat Statistik (BPS) Kabupaten Pidie belum dapat dilaksanakan sebagaimana mestinya, dikarenakan adanya beberapa faktor penghambat dalam pelaksanaannya.

\section{Perumusan Masalah}

Berdasarkan permasalahan di atas, maka dapat dirumuskan permasalahan yaitu :

1. Sampai sejauh mana proses manajemen perkantoran Badan Pusat Statistik (BPS) Kabupaten Pidie?

2. Faktor apa saja yang menjadi kendala dalam proses manajemen perkantoran Badan Pusat Statistik (BPS) Kabupaten Pidie?

\section{Tujuan Penelitian}

1. Untuk mengetahui sejauh mana manajemen perkantoran Badan Pusat Statistik (BPS) Kabupaten Pidie.

2. Untuk mengetahui factor yang menjadi kendala dalam proses manajemen perkantoran Badan Pusat Statistik (BPS) Kabupaten Pidie.

\section{Ruang Lingkup}

Ruang lingkup penelitian ini dibatasi pada hal-hal yang berkenaan dengan proses manajemen perkantoran Badan Pusat Statistik (BPS) Kabupaten Pidie.

\section{Hipotesis}

Dalam pelaksanaan manajemen perkantoran Badan Pusat Statistik (BPS) Kabupaten Pidie, menurut pengamatan penelitian atau hipotesa yang penulis lakukan, bahwa belum terlaksananya pelaksanaan manajemen secara baik, diduga terbatasnya kemampuan pengelola dalam menata manajemen perkantoran disamping sarana dan prasarana yang tersedia juga terbatas.

\section{METODE PENELITIAN \\ Lokasi Penelitian}

Lokasi penelitian yaitu Badan Pusat Statistik (BPS) Kabupaten Pidie.

\section{Populasi}

Populasi adalah jumlah seluruh karyawan Badan Pusat Statistik (BPS) Kabupaten Pidie, adalah 33 orang.

\section{Sampel Penelitian}

Menurut Kartono (1997), apabila populasi yang jumlahnya $10-100$ orang sebaiknya diambil sampel $100 \%$ atau perhitungan secara sensus. Jadi sampel bagian dari populasi dijadikan responden yaitu sebanyak 33 orang pegawai.

\section{Cara Memperoleh Data}

Data yang diperlukan untuk penelitian ini meliputi 2 (dua) jenis yaitu data primer dan data sekunder. Data primer yaitu data lapangan, untuk mendapatkan data tersebut perlu dilakukan penelitian lapangan yaitu dengan mewawancarai para responden dan menggunakan daftar pertanyaan yang telah disiapkan sebelumnya. Data sekunder yaitu data kepustakaan untuk mendapatkan dengan cara menelah sejumlah literature yang ada kaitannya dengan permasalahan yang sedang dibahas.

\section{Cara Menganalisa Data}

Semua data yang diperoleh dari hasil penelitian diolah dan dianalisis dengan menggunakan pendekatan kualitatif dan kuantitatif.

\section{PEMBAHASAN HASIL PENELITIAN}

Analisis Manajemen Perkantoran Badan Pusat Statistik (BPS) Kabupaten Pidie

Sebagaimana yang telah dikemukakan dalam hasil penelitian yang menunjukkan bahwa, sangat berat dan kompleknya tugas yang harus dilaksanakan oleh pegawai pada Badan Pusat Statistik (BPS) Kabupaten Pidie. Disamping harus menata manajemen dilingkungan kantor, juga harus melaksanakan tugas pemerintahan dibidang kegiatan statistik sesuai dengan ketentuan peraturan perundangundangan yang berlaku. 
Maka dalam proses manajemen perkantoran khususnya yang dilaksanakan dibawah Sub Tata Usaha yang menyusun rencana dan program kerja, menyusun anggaran dan pengelolaan keuangan, melaksanakan administrasi dan tatausaha, mengelola kepegawaian, perlengkapan kantor dan lain-lainya. Semua tugas-tugas perlu dilakukan secara efektif dan efesien berdasarkan ketentuan-ketentuan yang telah ditetapkan sebelumnya, jadi pegawai merupakan unsur penyelenggara dari tugastugas yang dibebankan padanya untuk dapat berjalan sebagaimana yang diharapkan. Mengurus tata persuratan baik yang menyagkut dengan surat masuk dan surat keluar maupun juga laporan dokumen merupakan salah satu tugas yang harus dilaksakan oleh Sub Tata Usaha Badan Pusat (BPS) Statistik Kabupaten Pidie.

Surat merupakan salah satu alat komunikasi tertulis yang berasal dari satu pihak dan ditujukan dari pihak lain untuk menyampaikan berita dengan demikian jelas bahwa surat sangat penting artinya dalam membantu memperlancar tercapainya tujuan organisasi. Maka surat menyurat sangatlah penting dalam suatu organisasi karena suratmenyurat merupakan salah satu bagian dari proses komunikasi dalam organisasi yang berbentuk tulisan, proses surat menyurat ini lebih diutamakan untuk lingkungan ekstern organisasi yang sangat berpengaruh dalam menciptakan link organisasi.

Maka perlu diusahakan agar Sub Tata Usaha Badan Pusat Statistik (BPS) Kabupaten Pidie dapat membuat surat maupun laporan dokumen dengan baik, sebab penilaian negatif terhadap surat dan laporan dokumen akan dapat mempengaruhi pula penilaian negatif dalam organisasi. Dengan adanya surat maupun laporan dokumen yang baik dan rapi, maka dapat mendukung tercapainya tujuan organisasi yaitu bisa bertahan dan bisa tumbuh berkembang.

Dari hasil penelitian bahwa dalam hal penyimpanan arsip Badan Pusat Statistik (BPS) Kabupaten Pidie sistem penyimpanannya perlu disempurnakan, demikian pula halnya dengan tenaga yang mengelola arsip tersebut juga perlu dibina dan diberikan keterampilan atau pendidikan khusus dibidang penataan arsiparsip kantor, hal ini bertujuan untuk menghindari terjadinya pemborosan dalam hal memanfatkan waktu dan tenaga, apabila sewaktu-waktu arsip-arsip tersebut dibutuhkan kembali untuk bebagai keperluan.

Kecakapan seorang pegawai sangat menunjang terhadap proses manajemen perkantoran pada sebuah organisasi, karena tanpa adanya pegawai yang terampil maka tidak mungkin dapat menunjang aktivitas kerja dan tidak dapat juga meningkatkan kemampuan kerja sehingga perlu pembinaan terhadap pegawai secara terus menerus.

Dalam hal pembinaan terhadap pegawai Badan Pusat Statistik (BPS) Kabupaten Pidie, perlu mengambil langkah-langkah dengan mengadakan pelatihan dan kursus, ini dilakukan dengan tujuan untuk meningkatkan keterampilan dan kemampuan pegawai dalam menata proses manajemen perkantoran, disamping itu pimpinan juga harus memberikan kesempatan kepada pegawai untuk melanjutkan pendidikan atau latihan untuk kursus-kursus yang diselenggarakan ditingkat Kabupaten maupun ditingkat propinsi karena perlu dilakukan guna untuk meningkatkan kemampuan dan semngat kerja dalam menjalankan proses manaajemen perkantoran.

Sesuai dan kenyataan yang ada yang didasari kepada data-data yang ditemui dari hasil penelitian lapangan menunjukan bahwa jumlah pegawai Badan Pusat Statistik (BPS) Kabupaten Pidie seluruhnya berjumlah 33 orang yang terdiri dari laki-laki 21 orang $(63,64 \%)$ dan perempuan 12 orang $(36,36 \%)$. Dari kenyataan tersebut dapat dikatakan bahwa jumlah pegawai Badan Pusat Statistik (BPS) Kabupaten Pidie relative sangat didominasi oleh pegawai laki-laki.

Ditinjaun dari segi kepangkatan, pegawai Badan Pusat Statistik (BPS) Kabupaten Pidie hanya tiga jenjang golongan pegawai, masing-masing adalah golongan IV berjumlah 1 orang (3\%), golongan III berjumlah 16 orang $(48,50 \%)$, golongan II berjumlah 16 orang $(48,50 \%)$. Berdasarkan kenyataan yang ada menunjukan bahwa pegawai Badan Pusat Statistik (BPS) Kabupaten Pidie adalah sebagian besar adalah golongan III dan II.Tingkat pendidikan Pegawai Negeri Sipil merupakan tolak ukur bagi seseorang yang hendak melamar pada sebuah instansi pemerintah maupun swasta karena faktor pendidikan sangat menentukan pula produktifitas kerja seorang pegawai.

Yang ditemui menunjukan bahwa tingkat pendidikan Pegawai Negeri Sipil pada 
Badan Pusat Statistik (BPS) Kabupaten Pidie, yaitu Sekolah Menengah Atas 23 orang ( 69,70 $\%)$, Sarjana S1 8 orang $(24,24 \%)$, dan Sarjana S2 2 orang $(6,06 \%)$. Melihat dari kenyataan yang telah disebutkan di atas dapat disimpulkan bahwa tingkat pendidikan Pegawai Negeri Sipil Badan Pusat Statistik (BPS) Kabupaten Pidie masih didominasi oleh pegawai yang berpendidikan Sekolah Menengah Atas (SMA).

Sebagaimana yang telah disajikan sebelumnya, bahwa pendidikan perjenjangan atau latihan jabatan bagi seorang Pegawai Negeri Sipil sangat mempengaruhi mutu dan keahlian bagi seorang pegawai, karena dengan mengikuti berbagai program latihan jabatan diharapkan pegawai yang bersangkutan lebih professional dalam menyelenggarakan tugasnya.

Kenyataan yang diperoleh dari hasil penelitian menunjukan bahwa hanya 3 orang Pegawai Badan Pusat Statistik (BPS) Kabupaten Pidie yang telah diberikan kesempatan untuk mengikuti latihan jabatan antara lain ADUM 1 orang (33,33\%) dan PIM IV 2 orang $(66,67 \%)$.Dalam pembinaan sumber daya manusia/pegawai Negeri Sipil dilingkungan Badan Pusat Statistik (BPS) Kabupaten Pidie banyak bidang yang perlu dilakukan pelatihan, sehingga pegawai yang bersangkutan benar-benar terampil dan mampu menjalankan berbagai tugas yang telah dibebankan kepadanya.

Didalam organisasi yang besar, maka seseorang administrator dalam menjalankan tugasnya harus di bantu oleh orang lain supaya seluruh kegiatan organisasi berjalan dengan baik dan lancar. Manajemen adalah suatu proses yang terdiri dari tindakan-tindakan yang dimulai dari penentuan tujuan sampai pengawasan, dimana masing-masing bidang digunakan baik ilmu pegetahuan maupun keahlian yang diikuti secara berurutan dalam rangka usaha mencapai sasaran yang telah ditetapkan semula. Dengan diterapkan manajemen yang baik, maka diharapkan seorang pegawai mempuyai keterampilan dan propesional dalam menjalankan tugasnya.

Bahwa Manajemen/Pembinaan Pegawai Negeri Sipil belum sepenuhnya dapat dilaksanakan Badan Pusat Statistik (BPS) Kabupaten Pidie, disamping itu pembinaan yang dilakukan oleh pimpinan juga relative kurang, hal ini didapati hanya sebagian dari pegawai Badan Pusat Statistik (BPS)
Kabupaten Pidie yang telah mengikuti latihan jabatan, dan juga sebagian yang kurang disiplin dalam melaksanakan tugasnya.

Formasi adalah susunan pangkat Pegawai negeri Sipil pada salah satu instansi. Formasi harus disusun sesuai dengan ketentuan yang telah ditetapkan. Kenyataan yang ditemui Badan Pusat Statistik (BPS) Kabupaten Pidie bahwa masih ada formasi yang belum terisi, dan selama dua tahun terakhir Badan Pusat Statistik (BPS) Kabupaten Pidie juga tidak diadakan penerimaan pegawai baru.

Untuk sarana dan prasarana yang dimiliki Badan Pusat Statistik (BPS) Kabupaten Pidie masih terbatas dan perlunya penambahan supaya efektif dalam pelaksanaan proses manajemen perkantoran. Jenis-jenis sarana yang ada pada Badan Pusat Statistik (BPS) Kabupaten Pidie yaitu :

Laptop 20 unit, yang digunakan oleh semua pegawai yang ada pada Badan Pusat Statistik (BPS) Kabupaten Pidie untuk kebutuhan kantor dalam keadaan kurang baik. Penyediaan laptop pada Badan Pusat Statistik (BPS) Kabupaten Pidie masih kurang, ini dapat dilihat dengan jumlah pegawai yang ada serta dengan tugas-tugas pemerintahan dibidang kegiatan statistik tidak sesuai dengan laptop yang tersedia. Lemari 3 pintu 2 unit dan lemari 2 pintu 3 unit, untuk menyimpan arsip kantor Badan Pusat Statistik (BPS) Kabupaten Pidie dan bahan-bahan penting lainnya, lemari tersebut berada pada ruang Kepala, Sub Tata Usaha, dan Seksi-seksi lainnya.

Filling kabinet 1 unit, untuk menyimpan dokumen pegawai, ini sangat memprihatinkan karena alat penyimpanan ini masih sangat mini, bisa kita simpulkan masih sangat kurang penyediaan fasilitas ini terutama demi kerapian penyimpanan dokumen di Badan Pusat Statistik (BPS) Kabupaten Pidie. Meja biro 4 unit dan meja setengah biro 12 unit, meja adalah salah satu komponen yang paling penting dari setiap kantor. Meja digunakan untuk menyimpan file dan dokumen, suratsurat penting, dan untuk menulis dan meletakkan komputer, tapi meja yang tersedia pada Badan Pusat Statistik (BPS) Kabupaten Pidie masih sangat kurang, jika dilihat dari jumlah pegawai Badan Pusat Statistik (BPS) Kabupaten Pidie.Penyediaan kursi pegawai Badan Pusat Statistik 15 unit, dan kursi putar 1 unit, jelas ini menunjukan penyediaan kursi pegawai masih sangat kurang.Penyediaan meja dan kursi tamu 1 unit, maka dapat disimpulkan 
bahwa penyediaan kursi tamu sudah memadai untuk kenyamanan para tamu.Kamera CCTV I unit, ini sudah memadai untuk keamanan kendaraan para pegawai Badan Pusat Statistik (BPS) Kabupaten Pidie.

Setelah penulis uraikan jenis-jenis sarana dan prasarana yang ada pada Badan Pusat Statistik (BPS) Kabupaten Pidie, maka diperoleh gambaran umum keadaan sarana dan prasarana yang dimiliki oleh Badan Pusat Statistik (BPS) Kabupaten Pidie bila dibandingkan dengan jumlah pegawai yang ada sebanyak 33 orang. Maka sarana dan prasarana belum memadai, dalam arti sarana yang tersedia belum dapat mencukupi kebutuhan para pegawai dalam melaksanakan tugasnya sehari-hari.

Dalam hal peralatan kantor penulis ingin mengemukakan tentang permasalahan yang menyangkut tentang pelaksanaan proses manajemen tentang hal-hal yang berkenaan dengan peralatan tersebut, seperti yang telah dikemukakan sebelumnya, peralatan atau sarana yang dimiliki oleh Badan Pusat Statistik (BPS) Kabupaten Pidie jumlahnya sangat terbatas maka dengan demikian dalam hal pelaksanan tugas sehari-hari dapat menimbulkan hambatan seperti dalam pembuatan laporan maupun surat-surat lainnya. Berdasarkan kenyataan dalam pelaksanaan pekerjaan seharusnya telah dapat dilaksanakan tepat waktu namun mengalami hambatan disebabkan terbatasnya sarana yang ada seperti laptop, hal ini jelas akan menghambat terwujudnya efesiensi kerja pegawai terutama ditinjau dari efesiensi waktu, dimana pegawai tersebut telah membuangbuang waktu dengan sia-sia karena menunggu pegawai lain selesai berkerja. Dengan demikian dapat dikatakan perlu adanya keseimbangan sarana dan prasarana agar mendukung terlaksanya efesiensi kerja pegawai.

Seperti yang telah dikemukakan diatas dimana jumlah lemari tempat penyimpanan arsip terbatas dengan demikian apabila ditinjau dari segi efesiensi kerja pegawai belum dapat dikatakan efesiensi, karena untuk menemukan atau mencari arsip surat memerlukan waktu yang agak lama. Dari hasil penelitian bahwa dalam hal penyimpanan arsip Badan Pusat Statistik (BPS) Kabupaten Pidie sistem penyimpanannya perlu disempurnakan, demikian pula halnya dengan tenaga yang mengelola arsip tersebut juga perlu dibina dan diberikan keterampilan atau pendidikan khusus dibidang penataan arsip-arsip kantor, hal ini bertujuan untuk menghindari terjadinya pemborosan dalam hal memanfatkan waktu dan tenaga, apabila sewaktu-waktu arsip-arsip tersebut dibutuhkan kembali untuk bebagai keperluan. Kecakapan seorang pegawai sangat menunjang terhadap proses manajemen perkantoran pada sebuah organisasi, karena tanpa adanya pegawai yang terampil maka tidak mungkin dapat menunjang aktivitas kerja dan tidak dapat juga meningkatkan kemampuan kerja sehingga perlu pembinaan terhadap pegawai secara terus menerus.

Dalam hal pembinaan terhadap pegawai Badan Pusat Statistik (BPS) Kabupaten Pidie, perlu mengambil langkah-langkah dengan mengadakan pelatihan dan kursus, ini dilakukan dengan tujuan untuk meningkatkan keterampilan dan kemampuan pegawai dalam menata proses manajemen perkantoran, disamping itu pimpinan juga harus memberikan kesempatan kepada pegawai untuk melanjutkan pendidikan atau latihan untuk kursus-kursus yang diselenggarakan ditingkat Kabupaten maupun ditingkat propinsi karena perlu dilakukan guna untuk meningkatkan kemampuan dan semngat kerja dalam menjalankan proses manaajemen perkantoran.

Pengawasan merupakan hal yang perlu dilaksanakan secara teratur terhadap bawahan agar pegawai dapat melaksanakan tugasnya dengan baik sesuai dengan apa yang telah digariskan. Berdasarkan kenyataan yang diperoleh menunjukan bahwa pengawasan terhadap bawahan sering dilakukan oleh aparat atau bagian yang dibentuk dalam organisasi, selain dari pada itu juga dilakukan pengawasan melekat. Setiap atasan berhak mengawasi bawahanya dalam melakukan tugas sehari-hari. Dari uraian ini dapat diambil suatu kesimpulan bahwa pengawasan atasan terhadap bawahan badan Pusat Statistik (BPS) Kabupaten Pidie dilaksanakan dengan baik sesuai dengan peraturan yang berlaku.

\section{Analisis Hambatan-Hambatan Yang Ditemui}

Dari uraian-uraian dalam bab-bab sebelumnya terutama dalam bab III yang merupakan bab hasil penelitian, dapat terlihat hambatan-hambatan yang dihadapi dalam proses manajemen perkantoran Badan Pusat Statistik (BPS) Kabupaten Pidie antara lain adalah : 
1. Terbatasnya kemampuan personil dalam menata manajemen perkantoran, kemampuan pegawai Badan Pusat Statistik (BPS) Kabupaten Pidie masih perlu mendapatkan pembinaan, karena berdasarkan data yang diperoleh hanya sebagian kecil dari pegawai yang telah mendapatkan kesempatan untuk mengikuti pendidikan dan latihan serta kursus-kursus yang bersifat tehnik yang tujuannya untuk meningkatkan mutu dan kemampuan sekaligus akan dapat memberikan dorongan kepada pegawai untuk terus meningkatkan prestasi kerja yang dibebankan padanya. Dengan demikian Badan Pusat Statistik (BPS) Kabupaten Pidie dalam usaha meningkatkan proses manajemen perkantoran perlu dibekali dengan tenaga-tenaga yang terampil dan berprestasi, dalam hal ini dapat diperoleh dengan memberikan pembinaan secara terus menerus sehingga pegawai tersebut bekerja seefesien mungkin.

2. Hambatan lain juga ditemukan adalah mengenai sarana dan prasarana yang belum memadai, sehingga para pegawai sering sekali merasakan kesulitan dalam melaksanakan tugasnya di Badan Pusat Statistik (BPS) Kabupaten Pidie.

\section{Analisis Upaya-Upaya Yang Dapat Dilakukan}

Untuk mengatasi dan menangulangi permasalahan yang timbul dan menjadi kendala dalam proses manajemen Badan Pusat Statistik (BPS) Kabupaten Pidie, khususnya pada Sub Tata Usaha perlu dilakukan beberapa upaya yang antara lain dalah sebagai berikut :

1. Kepada setiap pegawai Badan Pusat Statistik (BPS) Kabupaten Pidie perlu diberikan berbagai latihan atau kursuskursus dalam bidang manajemen perkantoran guna meningkatkan prestasi kerja.
2. Untuk kelancaran pelaksanaan tugas manajemen perkantoran Badan Pusat Statistik (BPS) Kabupaten Pidie, maka perlu dilengkapi sarana dan prasarana yang masih kurang sehingga pelaksanaan tugas dapat dilaksanakan sebagaimana yang diharapkan.

\section{PENUTUP}

Berdasarkan pada uraian yang telah disampaikan pada bab-bab sebelumnya terhadap permasalahan yang diteliti, akhirnya dikaji dan diberikan beberapa kesimpulan dan saran.

\section{Kesimpulan}

1. Proses manajemen perkantoran Badan Pusat Statistik (BPS) kabupaten Pidie, relatif belum terlaksana sebagaimana mestinya, dikarenakan ditemui beberapa faktor yang menjadi hambatan dalam pelaksanaannya.

2. Hambatan-hambatan yang ditemui antara lain adalah terbatasnya kemampuan personil dalam menata manajemen perkantoran antara lain lemahnya motifasi kerja, serta disiplin para pegawai relative sangat rendah dan masih terbatasnya sarana dan prasarana yang dimiliki, seperti laptop, filling kabinet, meja, dan kursi.

\section{Saran}

1. Disarankan supaya pimpinan Badan Pusat Statistik (BPS) Kabupaten Pidie dapat meningkatkan pembinaan bawahan dengan memberikan berbagai pendidikan pelatihan dalam bidang manajemen dan administrasi perkantoran.

2. Disarankan supaya sarana dan prasarana yang masih kurang pada Badan Pusat Statistik (BPS) Kabupaten Pidie hendaknya perlu ditambah lagi sesuai dengan kebutuhan kantor, agar dalam pelaksanaan kegiatan kantor dapat teratasi dengan baik. 